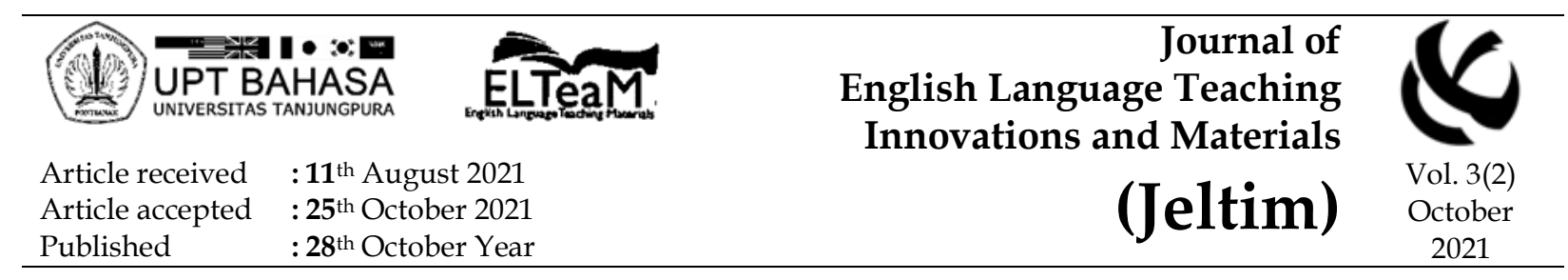

\title{
Word coinage communication strategy in learners of English oral interaction
}

\author{
Rushita Ismail1, *Muriatul Khusmah Musa' ${ }^{2}$, Rofiza Aboo Bakar ${ }^{3}$ \\ ${ }^{1}$ Academy of Language Studies, Universiti Teknologi MARA,Cawangan Pulau \\ Pinang,Malaysia \\ rushita@uitm.edu.my \\ ${ }^{2}$ Academy of Language Studies, Universiti Teknologi MARA,Cawangan Pulau \\ Pinang,Malaysia \\ muriatul557@uitm.edu.my \\ ${ }^{3}$ Academy of Language Studies, Universiti Teknologi MARA,Cawangan Pulau \\ Pinang,Malaysia \\ rofiza@uitm.edu.my
} DOI: http://dx.doi.org/10.26418/jeltim.v3i2.48593

\begin{abstract}
Coinage is one of the many creative strategies performed by language learners in instances when they are not able to retrieve the accurate lexical item from their limited linguistic knowledge. It is an issue of interests to language practitioners and learners and little research has been dealt on it. The study explored on the use of coinage strategies among Malaysian language learners in a pair work picture spot- the- difference narration activity. Thirty-two pre-selected items missing from one of the sets were to be identified and the session was video recorded. From the transcription data, the instances of semantic coinage strategies were found to be more frequently displayed as compared to grammatical coinage strategy when the learners encountered communication breakdowns. In semantic word coinage strategy, the learners formed lexical items by selecting two different features of the two interlanguage lexical items and combined them as a compound target language item. Grammatical word coinage strategy, on the other hand, was used by creating words which do not exist in the second language (L2) after an application of L2 rule to a L2 word. These communication strategies, in one way or another develop creativity and enhance the process of second language acquisition.
\end{abstract}

Keywords: coinage; communication; strategy; second language; learners 
How to cite this paper: Rushita Ismail, Muriatul Khusmah Musa \& Rofiza Aboo Bakar (2021). Word coinage communication strategy in learners of English oral interaction. Journal of English Language Teaching Innovations and Materials (Jeltim), 3(2), 99-108. DOI: http://dx.doi.org/10.26418/jeltim.v3i2.48593

To link to this article: http:/ / dx.doi.org/10.26418/jeltim.v3i2.48593

Language learners involved in an oral interaction are in the pursuit of one common goal and that is the successful communication of their intended messages. However, to communicate orally in the target language might not always turn out as desired. Language learners are often ingrained with communication shortcomings due to their inadequate linguistic knowledge (Rushita, 2012; Rushita \& Muriatul 2006). As a result, sometimes learners tend to resort to the use of some common communication techniques such as synonyms, descriptions, native language transfers or gestures in compensating the unattainable target form when facing difficulties in expressing intended ideas (Williams, 2006; Littlemore, 2003). All these different techniques that language learners use to communicate in a second language despite their shortcomings are known as communication strategies (CSs).

Numerous studies (Budiman \& Rushita 2013; Lindblad, 2011) have proven that communicative strategies help to maintain students' communication flow. Learners compensate their lexical deficiencies through gestures by altering, code switching and translating the difficult words or sometimes minimizing and simplifying the content of their message or speech. In short, to ensure effective communication, learners resort to different techniques of communication strategies based on their knowledge of the target language and native language items. Rushita (2012) highlighted that, code switching, approximation, use of allpurpose words, complete omission, word coinage, literal translation, circumlocution, appeals for assistance and nonverbal strategies are the common CSs that are widely used by many language learners. These CSs are categorized under achievement strategies and have been dealt to a great extent by researchers with the exception of coinage CS.

The study on coinage CS use is crucial as words are seen to be coined daily through the local printed and electronic media. According to Battarcharjee (2009) and Algeo (1998), even though coinage is an atypical process which produces doubtful words, it is a motivating process. The use of coinage CS indicates that learners are innovatively extending the words that are available to them when conveying the intended lexical items. However, learners' use of coinage CS is still underexplored particularly in Malaysian language learning context. 
Coinage is a unique CS that can be useful for incompetent language learners in achieving their language goal more effectively. Undoubtedly, investigating how coinage is used in learners' oral communication will also lead to a better understanding of students' speaking difficulties. In view of this, the study aims to unravel how students compensate their gaps in the target language through coinage CS and enhance the use of coinage CS in their daily oral interaction.

Coinage CS has been viewed as a creation of a new word by applying the existing knowledge of the target language that learners have (Tan et al. 2012, Rushita 2012). Being one of the components of communication strategies, there have been different definitions on word coinage CS.

Traditionally, word coinage can be defined as the invention of new words using learners' L2 item knowledge (Faerch and Kasper, 1983; Tarone, 1977). Tarone (1977) further stated that coinage can also be categorised as paraphrasing communication strategies wherein new words are created when the learner wants to express a desired concept (e.g. 'person worm' to refer to 'an animated caterpillar'. In addition, Faerch and Kasper (1983) claimed word coinage as one of the achievement communication strategies that helps learners to solve a communicative problem by expanding their communicative resources.

Later in 1990, Poulisse et. al p.60 categorized word coinage in morphological process creativity. They assert that "the speaker uses L2 rules of morphological derivation to create (what they assume to be) comprehensible L2 lexis (e.g. 'representator' for 'representative' or 'ironize' for 'to iron')". Dornyei (1995) defines word coinage as a learner's creation an L2 word based on his/her knowledge of morphological rules (e.g. 'vegetarianist' for 'vegetarian').

According to Dornyei and Kormos (1998) there are two types of word coinage; grammatical and semantical. The grammatical words coinage refers to the creation of a non-existing L2 word by applying a supposed L2 rule to an existing L2 word (e.g. 'dejunktion' and 'unjunktion', created from 'junk' and the prefixes 'de-' and 'un-', for 'clear the junk' and 'street clearing') while semantic word coinage deals with the creation of a non-existing L2 word by compounding words e.g. 'snowsculpture' for 'snowman'. Furthermore, word coinage is also known as 'creation of new words or phrases for words that learners do not know, for instance 'picture place' for 'art gallery' or the creation of an L2 word with the thought that the new created word might work or be understood, for example 'fish zoo' for aquarium (Faucette, 2001; Ellis,1997).

Recently there has been numerous studies on the study of coinage or currently termed as neologism which the authors regard in some aspect of word creation to be relevant to the study of word coinage in oral interaction. Dunaway (2011) highlights that the teaching of word coinage in a language classroom not 
only may poke fun in class but may get students to realize on the importance of proper usage and the capacity of words learned. Enesi (2017) regards coinage to be part of word formation theory to English speakers in vocabulary ESL class lessons. However, there has been no study conducted on word coinage in oral interaction. As coinages are words invented by accident or intentionally by learners, it is the intention of the authors to explore the use of word coinages in oral interaction and the types of word coinage created by language learners.

\section{METHOD}

The study utilized a qualitative research design of a descriptive interpretative case study. Participants were 16 dyads of undergraduate students enrolled in an intermediate language class at a local university. They were 17 males and 15 females aged 21 to 23 years old majoring in Applied Language studies.

Working on a picture-story narration of spot-the-difference task, each dyad was given two sets of comic series of picture with 32 lexical referents missing from one of the sets. Without looking at the partner's set, the learner had to describe as accurately as possible the picture narration for the partner to identify the missing items in his/her set. The 32 pre-selected target referents in the comic, spot-the-difference narration task are; feather, black neck tie, hat, puddle, handle bar moustache, humming, bus-stop sign, speed hump, barking, speeding, manhole cover, approaching, streetlight, fire hydrant, knocks, sidewalk, zebra-crossing, post-box, traffic-lights, bent, dented, glasses, sling bag, suspenders, striped, pimples, shocked, siren light, bonnet, flashing and shoe off.

The dyads spent twenty to thirty minutes for each task to be completed. The session was audio and video recorded. A stimulated recall interview was also carried out at the end of the task through the replay of the video recorded data to help researchers in interpreting and analyzing the data besides getting the authenticity and reliability of the data (Rubin \& Babbie, 2005; Rushita 2012). In analyzing CS in this study, the researchers adopted Dornyei and Kormos (1998) taxonomies of CS. CSs data were gathered and analyzed and word coinage CS frequency counts were recorded.

\section{FINDINGS}

This study was designed to identify the types of word coinage CS used and the regularity of its usage in an oral interaction. In analyzing the data, all verbal messages were transcribed. Initially, the identification of various CSs in this study was made by the authors and later instances of the production of word coinage were listed. 


\section{Semantic Word Coinage}

The term semantic word coinage CS was defined as "creating a nonexisting L2 word by compounding words" (Dornyei \& Kormos, 1988, p. 361). It is a formation of a L2 lexical item by selecting two different features of the two interlanguage lexical items and combines them as a compound target language item. This strategy, however, usually produces items which are non-existent in the target language.

In the Example 1, speaker A produces an item 'bodybelt' for the intended target language item 'suspenders' which does not exist in the target language but is contextually appropriate. Semantic word coinage is a formation of a L2 lexical item by selecting two different features of the two interlanguage lexical items and combining them as a compound target language item. The lexis produced from this CS is normally items which are non-existent in the target language.

Example 1

Dyad AB

REFERENT: Suspenders/braces

1 B: the strap..does it called a strap?

2 A: belt (..) I think heh!

3 B: *belt*

4 A: a bodybelt

5 B: a bodybelt (heh) heh!

RETROSPECTIVE COMMENTS:

I: why body belt?

A: it's around form this waist to the back so I just come up with that word.

B: it's a new word? Hahaha

The analysis of interactional data reveals that semantic word coinage strategy is produced more as compared to syntactic word strategy. Other compound L2 words created among others are 'curlkid' for 'curly haired boy', 'pumppipes' for 'fire hydrant', 'slantingbag' for 'sling bag' and 'lightbox' for 'siren light'.

\section{Grammatical Word Coinage}

In contrast to semantic word coinage, grammatical word coinage strategy is used by creating a word which does not exist in a L2 after an application of L2 rule to a L2 word. In the researchers' data however, learners often made use of this CS when they created the word 'bumper' by adding the noun suffix '-er' to the existing word 'bump' to convey the intended meaning of the word 'speed bump'. In another case of the categorization of grammatical word coinage strategy, the word 'speed hump' is replaced by 'humper'. Bialystok (1990) asserts that the word created by this strategy usually does not exist in interlanguage but 
in this case; the word 'bumper' and 'humper' do exist but the meanings of these words are not appropriate to the context of 'speed bump'.

Example 2

Dyad MN

REFERENT: road / speed bump/ traffic hump

$1 \mathrm{M}:$....there is a humper?

$2 \mathrm{~N}$ : where is it?

$3 \mathrm{M}$ : in front of the bicycle

$4 \quad \mathrm{~N}:(.$.$) a humper?$

5 M: like bumper

6 N: oh ya!

\section{RETROSPECTIVE COMMENTS:}

I: tell me. What is a humper?

A: it's a hump right? Why did I call it humper? I don't know.

The table below illustrates the frequency counts of the following semantic and grammatical coinage strategies used by each dyad in the study. There were a total of 24 gathered. These strategies have been seen to be utilized with other oral communication strategies by the dyads.

Table 1. Frequency Counts of Word Coinage CSs

\begin{tabular}{cccc}
\hline Dyad & Semantic & Grammatical & Total \\
\hline AB & 1 & 1 & 2 \\
\hline CD & 1 & 0 & 1 \\
\hline EF & 2 & 0 & 2 \\
\hline GH & 2 & 1 & 3 \\
\hline IJ & 1 & 1 & 2 \\
\hline KL & 0 & 0 & 0 \\
\hline MN & 3 & 1 & 4 \\
\hline OP & 2 & 2 & 4 \\
\hline QR & 3 & 1 & 4 \\
\hline ST & 0 & 0 & 0 \\
\hline UV & 1 & 1 & 2 \\
\hline Total & 16 & 8 & 24 \\
\hline & & &
\end{tabular}

Semantic word coinage items were found to have been produced more than grammatical word coinages by the learners in this current study. For the intended interlanguage item, 'fire hydrant', learners produced, 'waterpile', 'firepipes', 'pumppipes' and 'firemenpipe'. For the intended interlanguage item 'manhole cover', the learners formed 'enchantedhole', 'holestopper', 'raincover' and 'waterhole'. There were also compound words such as 'pantspuller', 'bodybelt' and 'stringshort' creatively produced by the learners for the target 
language referent object, 'suspenders'. In describing 'curly haired boy' the learners used compound word 'curlkid' whereas, 'slantingbag' and 'lightbox' were used for 'sling bag' and 'siren light' respectively.

The findings also revealed that the learners' use of grammatical word coinage strategy was not very frequent as semantic word coinage CS. Out of the 24 word coinage strategies; only 8 grammatical word coinages CS were utilized. For the intended item, 'speed hump', the learners produced 'humper' and 'bumper'. The word, 'slinger' for 'sling bag' was also created. For 'speeding', learners used 'speedily' instead, and for 'suspenders', learner created 'bracers'. Apart from these affixes used, some learners tend to use '-ing' form for words like 'siren' which turned out to be 'sirenning' and for 'knocks'; a learner used the word, 'knockingly'. Among all the affixes used, the affix 'er' was mainly used in most of the grammatical coinage word CS.

Some of these coined words do not exist in the target language and are contextually inappropriate. However, at the end of the strategic interaction, the learners and their interlocutors reached an agreement of meanings for the intended words and in most cases they fail in the attempt to create an accurate and appropriate lexis.

\section{DISCUSSION}

Instances where learners utilised the word coinage CS to compensate for breakdowns do occur in oral interaction. Learners tend to resort to word coinage CS when they were not able to retrieve suitable lexical items from their linguistics knowledge and at times they employed both semantic and grammatical word coinage strategies to compensate their language difficulties. These corroborate the ideas of Dornyei (1988), who suggested that when learners used these communication strategies, they were actually expanding their semantic and grammatical communicative resources. The use of semantic word coinage in this study was found to be more prominent than grammatical word coinage as the former serves the communicative purpose of the learners' immediate needs to avoid breakdowns in oral interactions (Abdullahi-Idiagbon \& Olaniyi, 2011).

The study also reveals that although the frequency of word coinage CS being used by the students was not high, they should be made aware of the strategy that they can employ to avoid communication breakdown. For this reason, Maleki (2010) highlights that, it is necessary to teach the word coinage CS in language classroom because exposing the learners to semantic and grammatical coinages activities may develop learners' strategic competence. In other words, teaching the students this strategy may encourage them to think and invent new words. Furthermore, with the constant evolvement of English 
language and the existence of the creation of new words, learners are to be taught that the words that they coined through this CS is commendable (Enesi, 2017; Dunaway, 2011).

\section{CONCLUSION}

In conclusion, the results of this study suggest that learners do utilise word coinage CS in oral interaction despite their limited linguistic knowledge and this helps learners to accomplish their targeted communication goals. Communication of meaning is successful through the use of coinage CSs though the lexical items produced are not accurate.

One possible area for future research would be to investigate how learners from higher intermediate and advanced levels of English proficiency could possibly utilise more of this CS in their communication. It will also be interesting to compare whether the use of word coinage CS among students of different cultures and gender may trigger more numbers of new creations of conspicuous words. Indeed, more studies are needed to fill the gap in knowledge on the aspects of word coinage CS and the process of second language acquisition.

\section{REFERENCES}

Abdullahi-Idiagbon, M.S. \& Olaniyi, O.K (2011). Coinages in Nigerian English: A Sociolinguistic Perspective. African Nebula, Issue 3, 2011

Algeo, J. (1998) "Vocabulary". In: Romaine, S. (ed.). The Cambridge History of the English Language.Volume 4: 1776-1997. Cambridge: Cambridge University Press.57-91.

Battarcharjee, D.S. (2009). Lexical Innovation on the Internet - Neologisms in Blogs. Phd Thesis. Zurich. University of Zurich. Poland.

Bialystok, E. (1990). Communication Strategies: A Psychological Analysis of Second. Oxford: Basil Blackwell.

Budiman Sabri Ahmad \& Rushita Ismail. (2013) Compensation Learning Strategies Employed by Adult ESL Learners of a University in Malaysia. Procedia - Social and Behavioral Sciences 90 (2014): 85. 
Dörnyei, Z., \& Kormos, J. (1998). Problem-solving mechanisms in L2 communication: A psycholinguistic perspective. Studies in Second Language Acquisition (20), 349-385.

Dunaway, M. (2011, December 12). Teaching the Power of Word Coinage. Retrieved from https://www.visualthesaurus.com/cm/teachersatwork/teaching the-power-of-word-coinage/

Ellis, R. (1997). Second Language Acquisition. Oxford Introductions to Language Study. Oxford, New York: Oxford University Press. ISBN 978-0-19 437212-1.

Enesi, M. (2017). The Effect of Teaching Word Formation Theory to English Students. European Journal of Language and Literature Studies. Jan-April 2073(1).7-12.

Faerch, C., \& Kasper, G. (1983). On identifying communication strategies in interlanguage. In C.Faerch, \& G. Kasper, Strategies in Interlanguage Communication (pp. 210-238). New York, NY: Longman.

Faucette, P. (2001). A pedagogical perspective on communication strategies: Benefits of training and an analysis of English language teaching materials. Second Language Studies (19), 1-40.

Lindblad, M. (2011). Communication Strategies in Speaking English as a Foreign Language In the Swedish 9th grade national test setting. Retrieved from https://www.divaportal.org/smash/get/diva2:453878/FULLTEXT01.p df

Littlemore, J. (2003). The communicative effectiveness of different types of communication strategy. System, 31 (3), 331-347.

Poulisse, N., Kellerman, E., Ammerlaan, T., \& Bongaerts, T. (1990). System and hierarchy in L2 compensatory strategies. In R. C. Scarcella, E. S.

Andersen, \& S. D. Krashen, In Developing Communicative Competence (pp. 163-178). New York: Newbury House.

Maleki, A. (2010). Techniques to Teach Communication Strategies. Journal of Language Teaching and Research, 1(5) 640-646. doi:10.4304/jltr.1.5.640646.

Rubin, A., \& Babbie, E. (2005). Research Methods for Social Work 5th ed. Belmont, CA: Brooks/Cole. 
Rushita Ismail. (2012). Communication Strategies and Collaboration of Malaysian ESL Learners in Oral Interaction, Phd thesis. Penang: Universiti Sains Malaysia, Malaysia.

Rushita Ismail \& Muriatul Khusmah Musa. (2006). An Investigation Into the Communication Strategies Employed by the ESL Malay learners at Malaysian Universities. Penang: UiTM BRC grant Research.

Tan, K.H, Nor Fariza MN, Mohd, NJ. (2012). Communication Strategies Among EFL Students - An Examination of Frequency of Use and Types of Strategies Used. GEMA Online ${ }^{\mathrm{TM}}$ Journal of Language Studies 831, 12(3).

Tarone, E. (1977). Conscious communication strategies in interlanguage: A progress report. In D.Brown, C. Yorio, \& R. H. Crymes, On TESOL' 77: Teaching and Learning ESL (pp. 194-203). Washington D.C.: TESOL.

Williams, J. (2006, February). Combining Communication Strategies and Vocabulary Development. Retrieved from The Internet TESL Journal Vol. XII, No. 2: http://iteslj.org.

\section{Authors' Brief CV}

Rushita Ismail is Associate Professor at the Academy of Language

Studies, Universiti Teknologi MARA Cawangan Pulau Pinang, Malaysia. She earned her Phd in Applied Linguistics from Universiti Sains Malaysia and her Master's degree in TESOL from Central Connecticut State University, USA. Widely published, her research areas include SLA, ELT and communication.

Muriatul Khusmah Musa is a Senior Lecturer in Academy of Language Studies, Universiti Teknologi MARA Cawangan Pulau Pinang, Malaysia. She holds a Master's Degree in English Language Studies \& Methods from the University of Warwick, United Kingdom and BHsc.in English Language \& Literature from International Islamic University, Malaysia. Her research interests are in the fields of ELT and language \& communication.

Rofiza Aboo Bakar is attached to Universiti Teknologi MARA Cawangan Pulau Pinang, Malaysia. A senior lecturer, she specializes in Educational Psychology particularly in English Language Teaching and Learning, Reading, Digital Story Telling and Creativity. 